\title{
Este número
}

\section{Maria Helena Serôdio}

Desta vez com coordenação de Mónica Guerreiro e Miguel-Pedro Quadrio, este número é o segundo andamento de um projecto de análise e reflexão que tomámos como programa para a criação desta revista. Prosseguimos aqui um mesmo caminho, mas explorando agora, naturalmente, outros lugares e outras perspectivas, observando, afinal, refracções de uma mesma realidade vasta e complexa, que exige, justamente porque o é, desdobramento de processos e uma permanente transversalidade de relações.

Tivemos a alegria de ver lançado o nosso primeiro número no Salão Nobre do Teatro Nacional D. Maria II, no dia 14 de Outubro, com o apoio do seu Director, António Lagarto, que generosamente mobilizou possibilidades e competências várias da sua equipa para que tudo se conjugasse de forma perfeita. E o "quadro" humano que encheu a sala - entre artistas, escritores, estudiosos, professores, críticos e público em geral - foi para nós um sinal inequivoco de que é enorme a responsabilidade, que nos cabe, não apenas de cumprir o programa que traçámos, mas também de estarmos atentos a uma realidade artística plural (e movente) e a um tecido teórico que se refaz continuadamente. Contámos, na ocasião, com uma sugestiva comunicação sobre a idade e a imagem do actor (num título que jogava curiosamente com uma rima interna: "L'acteur: entre l'âge et l'image") por parte de Georges Banu, Presidente Honorário da Associação Internacional de Críticos de Teatro (AICT / IATC) e membro do Conselho Consultivo da nossa revista.

E é neste patamar - entre a observação da realidade portuguesa e o vínculo a instâncias estrangeiras - que a revista pretende prosseguir o seu labor reflexivo: por um lado, porque a arte, o estudo, o humano enfim, não reconhece as fronteiras como factores limitativos, antes as mobiliza como factor importante de migrações e conjunções enriquecedoras; por outro, porque deliberadamente queremos instituir um diálogo entre gentes colocadas em lugares diferenciados.
Neste vivo encontro entre realidades diversas é-nos grato referir a saída de um número bilingue da revista UBU: Scènes d'Europe / European Stages inteiramente dedicado ao teatro português: o seu n. ${ }^{3} 3$, com o subtitulo Scènes portugaises / Portuguese Stages. Dirigida por Chantal Boiron, a revista apresenta um trabalho exemplar de interrogação do nosso "actual" património artístico, embora esteja naturalmente condicionada pelas dimensões físicas de uma publicação como esta, que, ainda por cima, escolhe (e sabemos que pelas melhores razões) dar a cada artigo a sua versão em inglês e em francês. É, enquanto projecto e realização, um desafio também para nós, e esperamos em breve poder articular melhor os nossos esforços, eventualmente numa rede que abranja mais revistas e possa - entre os seus membros - fazer circular imagens, olhares e saberes.

Outro importante cruzamento de fronteiras foi a realização no Porto do PoNTI (naquela que seria a sua 4. ${ }^{2}$ edição) que se assumiu neste ano como XIII Festival da União dos Teatros da Europa. Do que foi a sua notável intervenção artística na cidade fala-nos o artigo de Alexandra Moreira da Silva e Paulo Eduardo Carvalho, composto como numa partitura em diálogo, em que se cruzam, de forma feliz (embora em registo conciso, por razões óbvias), a argúcia da observação, o rigor da análise e o prazer de uma escrita sabedora e fluente. 0 artigo dános ainda conta da realização - no âmbito do festival de um Seminário para jovens críticos, uma realização conjunta da Associação Portuguesa de Críticos de Teatro (APCT) e da sua congénere internacional, que só foi possivel graças ao inestimável apoio e à competência organizativa do Teatro Nacional S. João. Prosseguiu, assim, também, o esforço que a APCT vem realizando no sentido de fazer confrontar jovens portugueses - críticos e estudiosos de teatro - com a realidade de outras práticas críticas e de outras construções cénicas, contando-se já em mais de vinte os que participaram em iniciativas deste género: de São Petersburgo a Almada, de Estrasburgo a Gdansk, de Grenoble a Praga e a Gotemburgo, entre outras cidades. 
E é justamente desta última cidade, da Suécia, que vem um depoimento sobre o Seminário da AICT que aí decorreu no âmbito de um festival de teatro e dança. Ocupa um espaço de "Notícias de fora" que se completam com dois outros textos sobre teatro visto recentemente em Londres e que parece sinalizar o ressurgimento do teatro político na cena internacional.

A atenção à realidade portuguesa emerge numa entrevista a Manuela de Freitas que recorda, com a veemência que coloca nas coisas em que acredita, um percurso de vida que é simultaneamente uma reivindicação ética (para si) e um testemunho interpelativo sobre o teatro em Portugal.

Outras formas de examinar aspectos da realidade teatral portuguesa traduzem-se aqui na crítica a alguns dos espectáculos que subiram recentemente à cena entre nós, mas também em recensões a peças de teatro, edições críticas, traduções e estudos que dão conta, ainda que de forma breve e incompleta (como é inevitável no espaço restrito de cada número), de um importante trabalho editorial, em que o papel do Centro de Estudos de Teatro acaba por ser muito relevante. A estes artigos se acrescenta a matéria do "Arquivo solto" que conta com uma interessante e bem documentada evocação do Teatro Avenida nas suas dimensões arquitectónica, empresarial e artística.

Se nos "Estudos aplicados" se fala ainda da realidade portuguesa - no (segundo) artigo que Luiz Francisco Rebello assina sobre revistas de teatro -, já João Maria André discorre, num panorama global, sobre a questão do corpo e da dor nas artes performativas, enquanto o encenador britânico Alexander Kelly escreve um breve testemunho sobre a sua prática do ensino da encenação, e o teatrólogo francês Patrice Pavis aborda, de forma judiciosa e sistemática, a questão geral da encenação num texto que é a forma abreviada de uma conferência que proferiu no Salão Nobre do Teatro Nacional D. Maria II, no Dia Mundial do Teatro de 2003, a convite do Centro de Estudos de Teatro, contando para isso com a colaboração daquele Teatro Nacional.

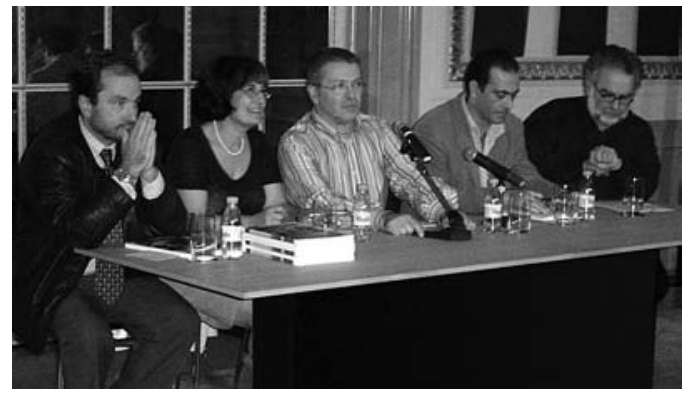

Na convergência de uma interrogação temática e de uma cartografia artística, o "Dossiê temático" aborda uma das mais relevantes práticas fundadoras da composição teatral, apresentando alguns dos cenógrafos que vêm marcando, de forma decisiva, a cena teatral portuguesa, enquanto o "Portefólio" relembra e celebra - em imagens os 30 anos da companhia de teatro 0 bando.

Esta atenção que aqui dispensamos à realidade teatral portuguesa é diversa nas modalidades de apreensão e dispersa nas referências teóricas e analíticas, mas é-o justamente porque essa realidade que nos importa estudar é em si plural e diversificada. A sua importância na experimentação de linguagens, na criação de um repertório de falas, gestos e imagens, bem como na construção de um imaginário, não vem sendo, todavia, reconhecida pelos poderes públicos que tendem a menorizar esta realidade cultural. A comprová-lo estão os reincidentes desapoios, os contínuos protelamentos, a persistente desatenção. 0 que nos espanta é que, apesar de tudo, essa realidade teime em existir e nela e para ela trabalhem pessoas que fazem disso um ideal de vida e um ideal de arte. E que, no intervalo dos seus afazeres e aflições, ainda reservam a paciência e a generosidade para nos emprestarem fotografias, dispensarem documentos e responderem a um sem número de perguntas. Para elas vai o nosso mais sincero agradecimento. 